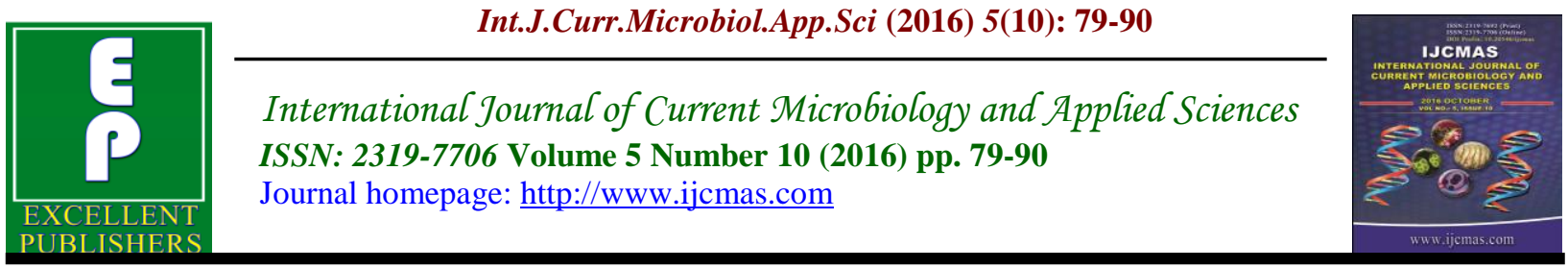

Original Research Article

http://dx.doi.org/10.20546/ijcmas.2016.510.010

\title{
Potential Use of Azotobacter and Phosphate Solubilizing Bacteria as Biofertilizer
}

\author{
A. Soma Prabha* \\ School of Biotechnology, Madurai Kamaraj University, Madurai-21, TamilNadu, India \\ *Corresponding author
}

Keywords

Rhizosphere, Azotobacter, Rastolnia sp, PGPR, and Artimia lethality.

\begin{tabular}{l}
\hline Article Info \\
\hline Accepted: \\
12 September 2016 \\
Available Online: \\
10 October 2016
\end{tabular}

\section{A B S T R A C T}

In the present investigation rhizosphere soil was collected in and around Chennai. The rhizosphere soils were serially diluted and pour plated on selected medium of pikovskay's media and winogradsky's media for isolation of bacteria. The isolated bacteria were identified based on morphological and biochemical tests. The results were compared with Bergy's manual of determinative bacteriology. Screening is done by growth promoting bacteria by seed germination. The efficiency on different crop plants in terms of growth and yield both length and biomass. From the results, it was noted as Azotobacter and Streptomyces. Molecular characterization of microbial isolates studied by $16 \mathrm{~S}$ RNA sequencing. Azotobacter and Rastolnia sp., were mass cultured and used in the experiment of plants and in probiotic fishes. The length and weight was measured in plant and fish. The isolated bacteria were inoculated in nutrient broth and fungus was inoculated in potato dextrose broth and it is extracted by using ethanol. Artimia lethality test was done by using brain shrimp in 96 titre well plate by selected organisms in bacteria and in fungi. The antibacterial activity test was done by kirbby boyer method in Azotobacter and phosphate solubilizing bacteria.

\section{Introduction}

Biofertilizer contains living microorganisms and promotes growth by increasing the availability of primary nutrient (nitrogen and phosphorus) to the host plant. Biofertilizer also provides nutrients required by the plants and helps to increase the soil quality with natural microorganism (Vessey, 2003). Some of the beneficial microbes used in biofertilizers are $\mathrm{N}_{2}$-fixing bacteria, phosphate-solubilizing microbes and mycorrhizae which are able to fix atmospheric nitrogen or solubilize phosphorus in the soil (Subba, 1999). Microorganisms are extensively used as biofertilizers in agricultural practices. The biofertilizers are the live or contain latent cell of beneficial microorganisms, which augment the availability of nutrients to the plants. The beneficial micro organisms are rhizobium, Azotobacters, azospirillum, cyanobacteria, phosphobacteria and mycorrhiza. Among these Azotobacters and phosphate bacteria play major role in the supply of nutrients and in the plant growth promoting activities. These bacteria are 
present in low populations in the natural environment (Subba Rao, 1997).

The multiplied artificially and incorborated into the agricultural lands in the form of biofertilizers. A lot of research work is available on the biofertilizers in agriculture practices. Nitrogen and phosphorus are the major plant nutrients, which are referred to as the master key element in crop production. It is a greater part of soil phosphorus (approximately 95-99\%) is present in the form of insoluble form; dominant in alkaline soil and unable to utilized by the plants (Lee et al., 2005).

Plants and microbes species have developed symbiosis or mutually beneficial relationships. Rhizobium is the root of legumes host nitrogen fixing bacteria which can invade root and get sugars from the plant. They convert large amounts of dinitrogen $\left(\mathrm{N}_{2}\right)$ from the atmosphere into forms that the plants can use (Zahran, 1999). Some soil bacteria, isolated from the root region of plants, are known to enhance growth of the plants. These beneficial freeliving soil bacteria are termed as plant growth promoting rhizobacteria (PGPR). The beneficial effect of PGPR is mediated through either direct or indirect mechanisms (Glick, 1995).

The PGPR also improve growth by indirect mechanisms such as, suppression of bacterial, fungal and nematode pathogens, and production of siderophores, $\mathrm{HCN}$, ammonia, antibiotics, volatile metabolites etc. (Glick, 1995). Symbiotic relationship between phosphate solublizing bacteria (PSB) and plants is synergistic in nature as bacteria provide soluble phosphate and plants supply root borne carbon compounds (mainly sugars), that can be metabolized for bacterial growth (Perez et al., 2007).
Azotobacter naturally fixes atmospheric nitrogen in the rhizosphere. There are different strains of Azotobacter each has varied chemical, biological and other characters. However, some strains have higher nitrogen fixing ability than others. Azotobacter uses carbon for its metabolismfrom simple or compound substances of carbonaceous in nature.

Azotobacters are aerobic, free-living, heterotrophic bacteria with unique ability of fixing atmospheric nitrogen. The bacteria are gram-negative, non motile, but often motile by peritrichous flagella. Azatobacters are highly important for their ability to fix molecular nitrogen, contributing to the productivity of any environment. They were proved experimentally to fix $10 \mathrm{mg}$ of atmospheric nitrogen per gram of carbohydrate consumed (Becking, 1971). A special group of bacteria (phosphate solubilising bacteria) occurring in sea water is capable of dissolving insoluble inorganic phosphorous into soluble inorganic phosphorous (Alexander, 1978; Chandrasekaran, 1966).

The present investigation is aimed towards the potential use of Azotobacter and phosphate solubilizing bacteria as biofertilizer.

\section{Materials and Methods}

\section{Sample collection}

The soil samples were collected from around Chennai. The samples were serially diluted and spread plate method was done. The pure cultures were streaked in pikovskay's medium and winogradsky medium. The pure cultures were stored in $4^{0} \mathrm{C}$ for further study.

Pikovskay's medium - In this medium is used to identify the phosphate solubilizing 
microorganisms. In that halo zone formed as positive result.

Winogradsky medium- In this medium is used to identify the Azotobacter.

Two strains have been selected for their efficiency of fixing the atmospheric nitrogen and or solubilizing the insoluble phosphate. These strains have scope for their possible utility as bio-fertilizers. It is necessary to identify the two strains at species levels prior to their economic utility. This chapter therefore, deals with the identification of most potent strains based on their cultural, morphological and biochemical characteristics.

\section{Cultural Characteristics}

The cultural characterization was studied based on morphological and biochemical characterization, such as abundance of growth, pigmentation, optical characteristics, form size margin and elevation were studied on nutrient agar plates.

\section{Germinating seed methods}

\section{Seed germination test}

The selected strains were bioassayed for their ability to promote/ inhibit seedling growth by using the method as described by Shende et al., (1977) and Ellicot and Lynch (1934) with modifications. Rice seeds were immersed in $95 \%$ ethanol for 20 sec. subsequently the seeds were immediately washed with sterile distilled water (3X10min) and incubated in $0.1 \%$ mercuric chloride solution for 4 minutes. Following this treatment, the seeds were washed repeatedly in excess amounts of sterile distilled water for 5-6 hours on a shaker before seeding them in petridishes containing in their respective medium containing at $10^{8}$ cells $\mathrm{ml}^{-1}$. The seeds were kept for 1 hour in the culture medium and decanted the medium. Five replicates of 100 seed of rice, green gram and brinjal were maintained for each bacterial species and incubated at $30^{\circ} \mathrm{c}$ for 3 days. After three days the percentage of seed germination was measured, shoot length and root length were measured in rice after 5 days of inoculation. In the case of green gram and rice, only root length was measured after 3 days of inoculation.

\section{Antibacterial Assay}

Antibacterial activity was carried out using disc diffusion method. The media was used Muller Hinton Agar (MHA). The tests were conducted at 3 different concentration of crude extract ( $5 \mathrm{mg}, 2.5 \mathrm{mg}$ and $1.5 \mathrm{mg} /$ disc). The plates were incubated for 24 hours at $37^{\circ} \mathrm{C}$.

\section{Artemia Lethality Assay}

After extraction with ethyl acetate the crude extract was tested for the Artemia salina toxicity assay, which is a simple, rapid and inexpensive bench top assay and considered as a useful tool for preliminary assessment of general toxicity (Meyer et al., 1982).

\section{Cultivation of Fungal Strains}

The fungal strains were inoculated in a 1000 $\mathrm{mL}$ Erlenmeyer flask containing $250 \mathrm{~mL}$ of potato dextrose broth (PDB). Cultivation was performed at room temperature under static conditions and daylight. Depending on the fungal growth, cultures on liquid medium were incubated for 2 weeks.

\section{Isolation of Genomic DNA}

The Genomic DNA was performed in selected bacterial isolates using QIAGEN DNA isolation kit (Qiagen). The sequence 
of 16S rRNA experiment was carried out.

\section{Polymerase Chain Reaction}

A pair of oligonucleotide primers is designed complementary to a target DNA molecule such that they can be extended by a DNA polymerase towards each other then the region of the template bounded the primers can be greatly amplified by carrying out cycles of denaturation, primer annealin and polymerization.

\section{Result and Discussion}

\section{Isolation of bacteria from rhizosphere soil}

The rhizosphere soils were collected from around chennai. The rhizosphere soils were used for isolation of bacteria from its soil. Zone formation occurs in the phosphate solubilizing bacteria. The total cultivable bacterial count of the entire soil was found to be $2.48 \times 10^{-3} \mathrm{CFU} / \mathrm{ml}$ and $3.19 \times 10^{-3}$ $\mathrm{CFU} / \mathrm{ml}$ in Azotobacter and phosphate solubilizing bacteria.

Different colony characteristics of the bacterial strains were observed on the surface of the Pikoskays medium and winogradsky's medium which was shown in (Figure.1 and 1.1). The isolated colonies were pure cultured and stored at $\quad 4^{\circ} \mathrm{C}$ for further use.

\section{Identification of the Isolated Bacteria}

The organisms were identified based on morphological and biochemical tests (Table: 1) according to the Bergey's manual of derminative bacteriology. Belong to the genus Azotobacter and Ralstonia respectively. Determinations of biochemical characterization of bacteria isolated from rhizosphere soil were identified as Azotobacter and ralstonia.

\section{Evaluation based on Seed Germination in Green Gram and Rice}

Seed germination in paddy was $40 \%$ and green gram was $80 \%$ in control. However, the seeds inoculated with bacteria exhibited an enhanced germination. The germination varied from 20 to $60 \%$ in rice and 80 to $100 \%$ in green gram depending on the strains Azotobacter used and 20 to $60 \%$ in rice and 80 to $90 \%$ in green gram depending on the strains of phosphate solubilizing bacteria (Table: 2 and Figure:2 and 2.1).

\section{Root Length in Rice and Green Gram}

The phosphobacterial strain increased the root nodules by $50 \%$. However Azotobacter strains decrease the root nodules by $29 \%$ in rice. The Azotobacter strain increased the root nodules by $34.75 \%$ in green gram. However phosphobacterial decrease the root nodules by $29 \%$ in green gram. (Table: 2 and Figure: 3 upto 3.3).

\section{Growth Measurement of Shoot in Green Gram and Rice}

The phosphobacterial strain increased the shoot by $60 \%$. However, Azotobacter strains decrease the shoot by $50 \%$ in green gram. The Azotobacter strain decreased the shoot by $30 \%$ in rice. However, phosphobacterial increase the shoot by $60 \%$ in rice. (Table:3).

\section{Antibacterial Activity Test}

In antibacterial activity test disc diffusion method is applied. Erythromycins, Chloramphenicol, Nalidicic acid are sensitive in phosphate solubilizing bacteria. Chloramphenicol, Nalidicic acid are sensitive and Erythromycin is resistant in Azotobacter (Table.4 and Figure.4). 
Artimia Lethality Test (Phosphate Solubilizing Bacteria and Azotobacter)

Phosphate solubilizing bacteria and Azotobacter are used in the artimia lethality test. The two strains are inoculated in nutrient broth. Kept for 24 hours incubation. Equal amount of ethyl acetate is added and extracted. Compare to Azotobacter phosphate solubilizing bacteria is good (Table.5 upto 5.4).

\section{Identification of Fungi}

In order to select the most promising fungal strains, the isolated fungi were cultivated in a small scale level in potato dextrose broth in an Erlenmeyer flask to gain enough extract for the bioactivity screening. A total of 10 strains were isolated and identified on the basis of their morphological characteristics (Table: 6). Based on the results of enzyme production, all the fungal strains, Mucor sp., Alternaria sp., Aspergillus terreus, Aspergillus flavipes, and Aspergillus niger were identified and chosen for their biological activities using different bioassay systems, and extract of fungus (Figure.5).

\section{Antibacterial Activity Test in Fungi}

In nutrient agar plate by using well cutter well is cut around the plate.The pathogenic bacteria such as Bacillus subtilis, Staphylococcus aerus, Salmonella paratyphi were swapped in the nutrient agar plates. Then the extract of fungus such as Aspergillus niger, Alternaria sp., Aspergillus flavipes, Mucor sp., Aspergillus terreus, Aspergillus flavus were inoculated in the petriplates. The zones were formed around the well (Table: 6.1 and Figure: 5.1).

\section{Artimia Lethality Assay in Fungi}

Aspergillus Niger and Aspergillus flavus are good in artimia lethality assay in fungi
(Table: 6.2).

\section{S RNA Sequencing}

The bacterial species was identified as rastonia species. The PCR amplification profile of selected strain. The condition is about $1 \%$ electrophoresis. (Figure: 6). The genomic DNA of two bacterial isolates in figure (6.1).

5'TGCCCCACATGATAACGGTTCCCTT GCAACTCTCACGCAGTGGGGGAG CCTTGCTTCCCTGCCAGCGAGTGGCG AACCGGTTATTAATCATCAGTAATGC CCTGTAGTGGGGGATAACTAGTCGAA AGATTAACTAATACCGCAAACACCTG AGGGTGAAAGTGGGCGACCGCAGGC CTCATGCTATATGAGCGGCGATGTCT GATTACCTAGTTGGTGGGGTAAAGGC CTACCAAGGCGACCATCAGTAGCTGG TCTGACAGGACGATCAGCCACACTGG GACTGACACACGGCCCACACTCCTAC GGGAGGCAGCAGTGGGGAATTTTGG ACATGGGCGAAACCCTGATCCAGCA ATGACGCGTGTGTGAAGAAGGCCTTC GGGTTGTAAAGCACTTTTGTCCGGAA AGAAATGGCTCTGGTTAATACCCGGA GTTGATGACGGTACCGGAAGAATAAC GACCGGCTAACTCCGTGCCAGCAGCC GCCGTAATACGTAGGGTCCAAGCGTT AATCGGAATTACTGGGCATAAAGCGT GCGCAGGCGGTTGTGC3'. Ic164817 Ralstonia sps. M1 $16 \mathrm{~S}$ ribosomal RNA partially sequenced. PCR amplification profile of selected strain and genomic DNA. It has 1500 base pair sequence. Ralstonia maninitolylitica strain is found by sequencing ang biochemical characterization.

In conclusion, Out of 10 strains, the best strains of Azotobacter and phosphate solubilizing bacteria were selected for their high beneficial activities. Further study was designed for characterization of the bacterial strains. Two selected strains were identified 
at species level based on their designed to test the utility of the identified morphological, culture and biochemical characteristics. Further experiment was strains as biofertilizer for rhizosphere soil.

Table.1 Cultural and biochemical characteristics of the selected bacterial strains

\begin{tabular}{|c|c|c|c|}
\hline S.NO & Characteristics & AZ0 & PSB \\
\hline 1 & Gram staining & Gram -negative & Gram-negative \\
\hline 2 & Bacterial shape & Ovoid & Rods \\
\hline \multicolumn{4}{|c|}{ Culture characteristics on agar slants } \\
\hline 3 & Abundance of growth & Moderate & Moderate \\
\hline 4 & optical characteristics & Transparent & Opague \\
\hline 5 & $\begin{array}{c}\text { cultural characteristics on } \\
\text { nutrient agar plates }\end{array}$ & & \\
\hline 6 & Size & Small & Small \\
\hline 7 & Elevation & Convex & Flat \\
\hline & $\begin{array}{c}\text { Appearance on nutrient } \\
\text { broth cultures }\end{array}$ & Sediment & Pellicle \\
\hline 8 & Motility & Motile & Motile \\
\hline \multicolumn{4}{|c|}{ Intra cellular enzyme } \\
\hline 9 & \multicolumn{3}{|c|}{ Carbohydrate Fermentation } \\
\hline 10 & Sucrose & - & - \\
\hline 11 & Fructose & - & - \\
\hline 12 & Maltose & - & - \\
\hline 13 & Mannitol & - & - \\
\hline 14 & $\begin{array}{l}\text { Hydrogen sulphide } \\
\text { production }\end{array}$ & Not tested & Not tested \\
\hline 15 & Nitrate reduction & - & - \\
\hline & IMViC test & & \\
\hline 16 & Indole production & - & - \\
\hline 17 & Methyl red reaction & - & + \\
\hline 18 & $\begin{array}{c}\text { Voges proskauer } \\
\text { Reaction }\end{array}$ & - & - \\
\hline 19 & Citrate utilization & + & + \\
\hline 20 & Urease activity & - & - \\
\hline 21 & Catalase activity & + & + \\
\hline 22 & Oxidase activity & + & + \\
\hline \multicolumn{4}{|c|}{ Extra cellular enzyme } \\
\hline 23 & Starch hydrolysis & + & + \\
\hline 24 & Lipid hydrolysis & + & - \\
\hline 25 & Gelatin hydrolysis & + & - \\
\hline
\end{tabular}


Table.2 Evaluation based on seed germination and root nodules in green gram and rice

\begin{tabular}{|c|c|c|c|c|}
\hline S.NO & \multicolumn{2}{|c|}{ GREEN GRAM } & \multicolumn{2}{|c|}{ RICE } \\
\hline Strains & $\begin{array}{c}\text { Seed } \\
\text { germination } \\
(\boldsymbol{\%})\end{array}$ & $\begin{array}{c}\text { Root nodules } \\
(\mathbf{m m})\end{array}$ & $\begin{array}{c}\text { Seed } \\
\text { germination } \\
(\boldsymbol{\%})\end{array}$ & $\begin{array}{c}\text { Root } \\
\text { nodules } \\
(\mathbf{m m})\end{array}$ \\
\hline Control & 80 & 30.25 & 40 & 27.15 \\
\hline Azo 1 & 100 & 28.8 & 20 & 23 \\
\hline Azo2 & 90 & 20.6 & 30 & 14.3 \\
\hline Azo3 & 80 & 34.75 & 60 & 14 \\
\hline Azo4 & 100 & 16 & 20 & 29 \\
\hline Psb1 & 80 & 25.75 & 20 & 13.5 \\
\hline Psb2 & 80 & 34.25 & 60 & 12 \\
\hline Psb3 & 90 & 22.6 & 20 & 10.16 \\
\hline Psb4 & 80 & 30 & - & - \\
\hline Psb5 & 90 & 21.3 & 20 & 50 \\
\hline Psb6 & 80 & 36.25 & 50 & 37.8 \\
\hline
\end{tabular}

Table.3 Growth measurement of green gram and rice

\begin{tabular}{|c|c|c|c|c|}
\hline & \multicolumn{2}{|c|}{ Green gram } & \multicolumn{2}{c|}{ Rice } \\
\hline Strains & Millimeter & Percentage & Millimeter & Percentage \\
\hline Control & 99 & 40 & 62.4 & 50 \\
\hline Azo 1 & - & - & 62.6 & 30 \\
\hline Azo 2 & 90 & 20 & 47.5 & 20 \\
\hline Azo 3 & 103.66 & 60 & 94.6 & 30 \\
\hline Azo 4 & 73.88 & 50 & 63 & 30 \\
\hline Psb 1 & 75 & 10 & 58.5 & 20 \\
\hline Psb 2 & 107.8 & 50 & 84 & 60 \\
\hline Psb 3 & 104.6 & 30 & 117 & 40 \\
\hline Psb 4 & 94.4 & 50 & 50 & 10 \\
\hline Psb 5 & 91.6 & 30 & 41 & 10 \\
\hline Psb 6 & - & - & 89.8 & 60 \\
\hline
\end{tabular}

Table.4 Antibacterial activity test

\begin{tabular}{|c|c|c|c|c|c|}
\hline S.No & Antibiotic discs & $\begin{array}{c}\text { Phosphate Solubilizing } \\
\text { Bacteria }\end{array}$ & Mm & Azotobacter & Mm \\
\hline 1 & Erythromycin & Sensitive & 13 & Resistant & - \\
\hline 2 & Chloramphenicol & Sensitive & 15 & Sensitive & 8 \\
\hline 3 & Nalidiric acid & Sensitive & 14 & Sensitive & 16 \\
\hline
\end{tabular}


Table.5 Artimia lethality test (Phosphate solubilizing bacteria and Azotobacter)

\begin{tabular}{|c|c|c|c|c|c|c|c|c|c|c|c|c|c|c|c|c|}
\hline Content & \multicolumn{2}{|c|}{ Psb1 } & \multicolumn{2}{|c|}{ Azo1 } & \multicolumn{2}{|c|}{ Psb2 } & \multicolumn{2}{|c|}{ Azo2 } & \multicolumn{2}{c|}{ Psb3 } & \multicolumn{2}{c|}{ Azo3 } & \multicolumn{2}{|c|}{$\begin{array}{c}\text { Positive } \\
\text { (Seawater) }\end{array}$} & \multicolumn{2}{c|}{$\begin{array}{c}\text { Negative } \\
\text { (Dmso) }\end{array}$} \\
\hline$\mu \mathrm{g}$ & $\mathrm{A}$ & $\mathrm{D}$ & $\mathrm{A}$ & $\mathrm{D}$ & $\mathrm{A}$ & $\mathrm{D}$ & $\mathrm{A}$ & $\mathrm{D}$ & $\mathrm{A}$ & $\mathrm{D}$ & $\mathrm{A}$ & $\mathrm{D}$ & $\mathrm{A}$ & $\mathrm{D}$ & $\mathrm{A}$ & $\mathrm{D}$ \\
\hline $1000 \mu \mathrm{g}$ & - & 10 & - & 10 & - & 10 & - & 10 & - & 10 & - & 10 & 10 & - & - & 10 \\
\hline $500 \mu \mathrm{g}$ & - & 10 & - & 10 & - & 10 & - & 10 & - & 10 & - & 10 & 10 & - & - & 10 \\
\hline $250 \mu \mathrm{g}$ & - & 10 & - & 10 & - & 10 & - & 10 & - & 10 & - & 10 & 10 & - & - & 10 \\
\hline $125 \mu \mathrm{g}$ & 1 & 9 & 1 & 9 & 1 & 9 & 1 & 9 & 1 & 9 & 1 & 9 & 10 & - & - & 10 \\
\hline $62.5 \mu \mathrm{g}$ & 3 & 7 & 4 & 6 & 3 & 7 & 4 & 6 & 3 & 7 & 4 & 6 & 10 & - & - & 10 \\
\hline $31.25 \mu \mathrm{g}$ & 5 & 5 & 7 & 3 & 5 & 5 & 7 & 3 & 5 & 5 & 7 & 3 & 10 & - & - & 10 \\
\hline
\end{tabular}

Table.5.1 Initial weight and length of Probiotic in fish $\left(1^{\text {st }}\right.$ week $)$

\begin{tabular}{|c|c|c|c|c|c|c|}
\hline S.NO & \multicolumn{2}{|c|}{ Control } & \multicolumn{2}{c|}{ Phosphate solubilizing bacteria } & \multicolumn{2}{c|}{ Azotobacter } \\
\hline & Weight & $\mathbf{C m}$ & Weight & $\mathbf{C m}$ & Weight & Cm \\
\hline 1 & 2.51 & 4.3 & 2.11 & 4.2 & 2.54 & 4.6 \\
\hline 2 & 2.49 & 4.6 & 2.80 & 5 & 1.62 & 3.8 \\
\hline 3 & 1.66 & 4.0 & 2.90 & 4.5 & 2.12 & 4.5 \\
\hline 4 & 1.99 & 4.5 & 2.23 & 4.4 & 2.42 & 4.5 \\
\hline 5 & 0.94 & 2.5 & 2.27 & 4.0 & 1.52 & 4.3 \\
\hline 6 & 1.76 & 4.0 & 2.48 & 4.5 & 1.78 & 4.0 \\
\hline 7 & 1.89 & 4.7 & 1.92 & 4.0 & 2.62 & 4.5 \\
\hline 8 & 1.89 & 4.0 & 2.10 & 4.0 & 2.60 & 4.6 \\
\hline 9 & 1.63 & 3.5 & 2.47 & 4.3 & 3.20 & 4.8 \\
\hline 10 & 1.49 & 4.0 & 2.9 & 4.5 & 1.90 & 4.0 \\
\hline 11 & 1.37 & 3.5 & 0.75 & 3.2 & 1.36 & 3.8 \\
\hline 12 & 1.53 & 3.8 & 1.32 & 3.5 & 1.1 & 3.4 \\
\hline 13 & 2.63 & 4.6 & 1.23 & 3.8 & 1.77 & 4.0 \\
\hline
\end{tabular}

Table.5.2 Weight and length of Probiotic in fish ( $2^{\text {nd }}$ week)

\begin{tabular}{|c|c|c|c|c|c|c|}
\hline S.No & \multicolumn{2}{|c|}{ Control } & \multicolumn{2}{c|}{ Phosphate solubilizingbacteria } & \multicolumn{2}{c|}{ Azotobacter } \\
\hline & Weight & Cm & Weight & Cm & Weight & Cm \\
\hline 1 & 1.65 & 3.6 & 3.58 & 4.5 & 2.06 & 4.0 \\
\hline 2 & 1.84 & 4.1 & 3.76 & 4.9 & 5.24 & 4.9 \\
\hline 3 & 2.44 & 4.2 & 3.20 & 4.5 & 3.36 & 4.7 \\
\hline 4 & 3.16 & 4.6 & 2.68 & 5.0 & 5.75 & 4.4 \\
\hline 5 & 2.90 & 4.7 & 1.81 & 3.6 & 3.03 & 4.7 \\
\hline 6 & 2.56 & 5.0 & 4.11 & 5.2 & 2.62 & 4.3 \\
\hline 7 & 1.91 & 3.9 & 3.54 & 4.3 & 4.70 & 4.4 \\
\hline 8 & 2.25 & 4.9 & 3.34 & 4.2 & 1.60 & 3.7 \\
\hline 9 & 1.88 & 4.8 & 2.71 & 4.2 & 2.89 & 4.5 \\
\hline 10 & 3.06 & 4.2 & 1.48 & 4.0 & 2.68 & 4.0 \\
\hline 11 & 2.91 & 4.6 & .96 & 3.3 & 3.33 & 4.3 \\
\hline
\end{tabular}


Table.5.3 Weight and length of probiotic in fish (3rd week)

\begin{tabular}{|c|c|c|c|c|c|c|}
\hline S.No & \multicolumn{2}{|c|}{ Control } & \multicolumn{2}{c|}{ Phosphate solubilizing bacteria } & \multicolumn{2}{c|}{ Azotobacter } \\
\hline & Weight & Cm & Weight & Cm & Weight & Cm \\
\hline 1 & 2.81 & 4.6 & 2.25 & 4.3 & 2.21 & 5.0 \\
\hline 2 & 3.32 & 4.0 & 2.13 & 4.9 & 2.23 & 4.3 \\
\hline 3 & 2.81 & 4.6 & 2.15 & 4.4 & 2.34 & 4.2 \\
\hline 4 & 2.68 & 4.4 & 1.88 & 4.0 & 2.02 & 4.5 \\
\hline 5 & 2.98 & 4.8 & 1.75 & 4.2 & 3.11 & 5.3 \\
\hline
\end{tabular}

Table.5.4 Weight and length of probiotic in fish (4th week)

\begin{tabular}{|c|c|c|c|c|c|c|}
\hline S.No & \multicolumn{2}{|c|}{ Control } & \multicolumn{2}{c|}{ Phosphate solubilizing bacteria } & \multicolumn{2}{c|}{ Azotobacter } \\
\hline & Weight & Cm & Weight & Cm & Weight & Cm \\
\hline 1 & 2.57 & 4.6 & 2.05 & 4.1 & 2.77 & 4.8 \\
\hline 2 & 2.26 & 4.5 & 1.80 & 3.6 & 3.68 & 4.9 \\
\hline 3 & 2.0 & 4.0 & 2.11 & 4.7 & 2.19 & 4.0 \\
\hline 4 & 1.59 & 3.5 & 2.11 & 4.4 & 2.32 & 4.5 \\
\hline 5 & 2.30 & 4.3 & 1.98 & 4.1 & 2.40 & 4.2 \\
\hline
\end{tabular}

Table.6 Artimia lethality assay in fungi

\begin{tabular}{|l|l|l|}
\hline S.No. & Strain code & Name of the Fungi \\
\hline 1 & R-f-leaf 1 & Aspergillus niger \\
\hline 2 & R-f-stem 3 & Aspergillus niger \\
\hline 3 & A-stem 1 & Alternaria sp. \\
\hline 4 & A-f-leaf 3 & Aspergillus flavipes \\
\hline 5 & R-root 1 & Mucor sp. \\
\hline 6 & A-F-leaf 1 & Aspergillus terreus \\
\hline 7 & R-f-stem 2 & Aspergillus niger \\
\hline 8 & A-f-leaf 2 & Aspergillus niger \\
\hline 9 & A-f-root 1 & Aspergillus flavus \\
\hline 10 & R-f-stem 1 & Aspergillus flavus \\
\hline
\end{tabular}

Table.6.1 Antibacterial activity test in fungi

\begin{tabular}{|c|c|c|c|c|}
\hline S.NO & FUNGUS & BS & SA & SP \\
\hline 1 & R-f-leaf 1 & - & - & $3 \mathrm{~mm}$ \\
\hline 2 & A- stem 1 & $12 \mathrm{~mm}$ & $13 \mathrm{~mm}$ & $14 \mathrm{~mm}$ \\
\hline 3 & R- root 1 & $13 \mathrm{~mm}$ & $8 \mathrm{~mm}$ & $12 \mathrm{~mm}$ \\
\hline 4 & A-F-leaf 1 & $12 \mathrm{~mm}$ & $11 \mathrm{~mm}$ & $12 \mathrm{~mm}$ \\
\hline 5 & A-f-root 1 & $11 \mathrm{~mm}$ & $7 \mathrm{~mm}$ & $18 \mathrm{~mm}$ \\
\hline
\end{tabular}


Table.6.2 Artimia lethality test (fungi)

\begin{tabular}{|c|c|c|c|c|c|c|c|c|c|c|c|c|c|c|c|c|c|c|c|c|}
\hline & \multicolumn{2}{|l|}{1} & \multicolumn{2}{|l|}{2} & \multicolumn{2}{|l|}{3} & \multicolumn{2}{|l|}{4} & \multicolumn{2}{|l|}{5} & \multicolumn{2}{|l|}{6} & \multicolumn{2}{|l|}{7} & \multicolumn{2}{|l|}{8} & \multicolumn{2}{|l|}{9} & \multicolumn{2}{|l|}{10} \\
\hline Concentration & $\mathrm{D}$ & $\bar{A}$ & $\mathrm{D}$ & $\bar{A}$ & $\mathrm{D}$ & $\mathrm{A}$ & $\mathrm{D}$ & $\mathrm{A}$ & $\mathrm{D}$ & A & $\mathrm{D}$ & $\mathrm{A}$ & $\mathrm{D}$ & $\mathrm{A}$ & $\mathrm{D}$ & $\mathrm{A}$ & $\mathrm{D}$ & $\mathrm{A}$ & $\mathrm{D}$ & $\mathrm{A}$ \\
\hline $1000 \mu \mathrm{g}$ & 10 & - & 10 & - & 10 & - & 10 & - & 10 & - & 10 & - & 10 & - & 10 & - & 10 & - & 10 & - \\
\hline $500 \mu \mathrm{g}$ & 10 & - & 10 & - & 10 & - & 10 & - & 10 & - & 10 & - & 10 & - & 10 & - & 10 & - & 10 & - \\
\hline $250 \mu \mathrm{g}$ & 10 & - & 10 & - & 10 & - & 9 & 1 & 10 & - & 10 & - & 10 & - & 10 & - & 9 & 1 & 10 & - \\
\hline $125 \mu \mathrm{g}$ & 10 & - & 9 & 1 & 9 & 1 & 7 & 3 & 8 & 2 & 9 & 1 & 10 & - & 10 & - & 8 & 2 & 10 & - \\
\hline $62.5 \mu \mathrm{g}$ & 10 & - & 9 & 1 & 8 & 2 & 4 & 6 & 7 & 3 & 8 & 2 & 9 & 1 & 10 & - & 7 & 3 & 10 & - \\
\hline $31.25 \mu \mathrm{g}$ & 10 & - & 8 & 2 & 7 & 3 & 2 & 8 & 5 & 5 & 7 & 3 & 7 & 3 & 10 & - & 7 & 3 & 10 & - \\
\hline $\begin{array}{l}\text { NEGATIVE } \\
\text { CONTROL }\end{array}$ & 10 & - & 10 & - & 10 & - & 10 & - & 10 & - & 10 & & 10 & - & 10 & - & 10 & - & 10 & - \\
\hline $\begin{array}{l}\text { POSITIVE } \\
\text { CONTROL }\end{array}$ & - & $\begin{array}{l}1 \\
0\end{array}$ & - & $\begin{array}{l}1 \\
0\end{array}$ & - & 10 & - & $\begin{array}{l}1 \\
0\end{array}$ & - & 10 & - & 10 & - & 10 & - & 10 & - & 10 & - & 10 \\
\hline
\end{tabular}

Figure:1.Pure culture of microorganisms from root soil inselected media(Pikovskay'sMedia)

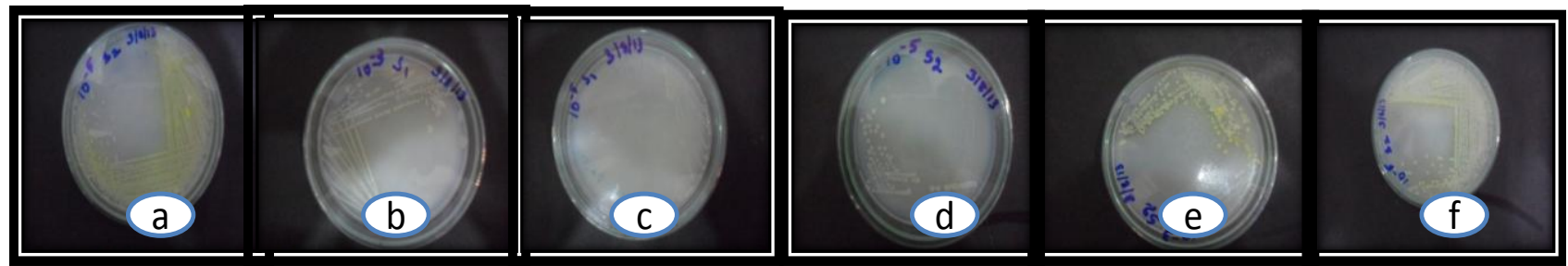

Figure: 1.1: Pure culture of microorganisms from root soil in selected media (winogradskay's

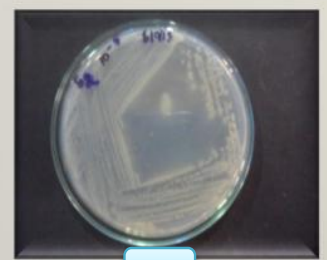

a

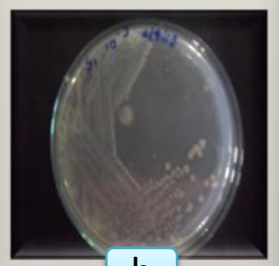

b

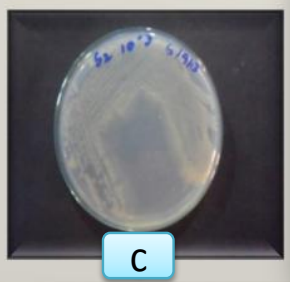

C
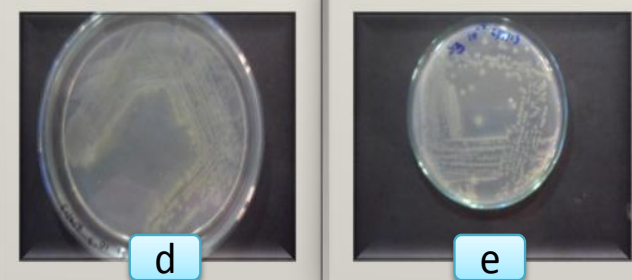

Figure:2: Seed Germination (Green Gram) Figure: 2.1 Seed Germination (Rice)
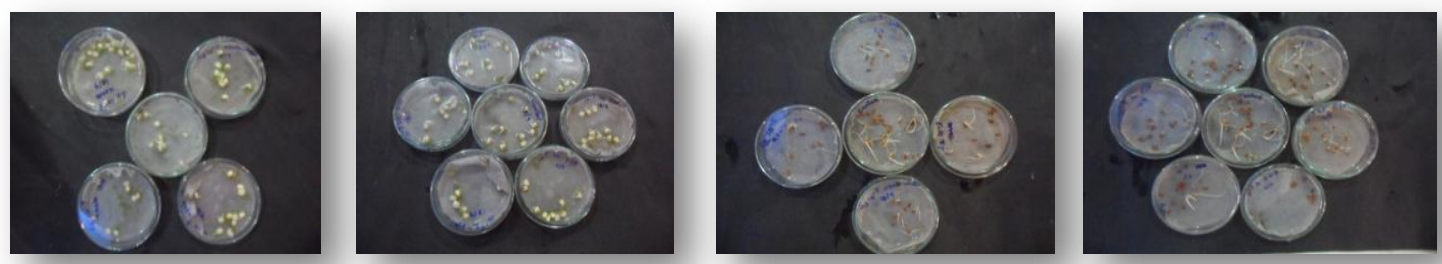

a) azo

b) psb

c) azo

d) $p s b$ 


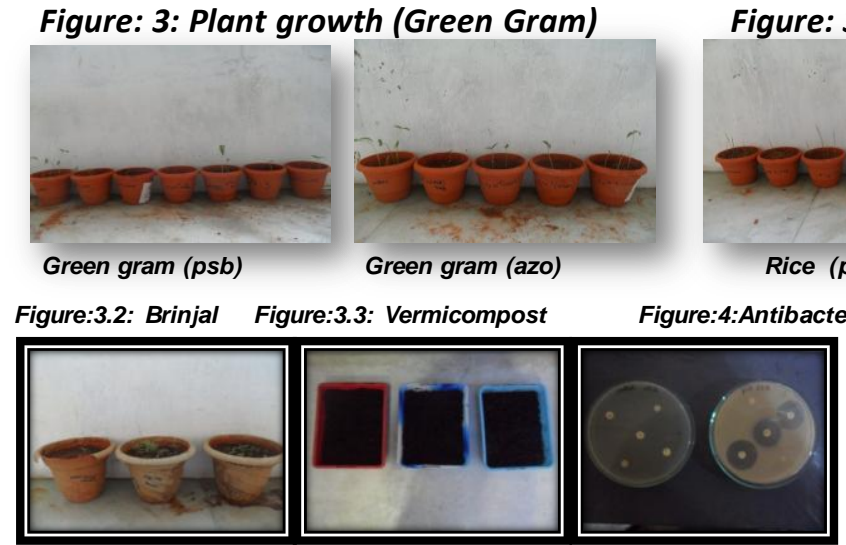

Fig: 5.1: Activity test in fungi

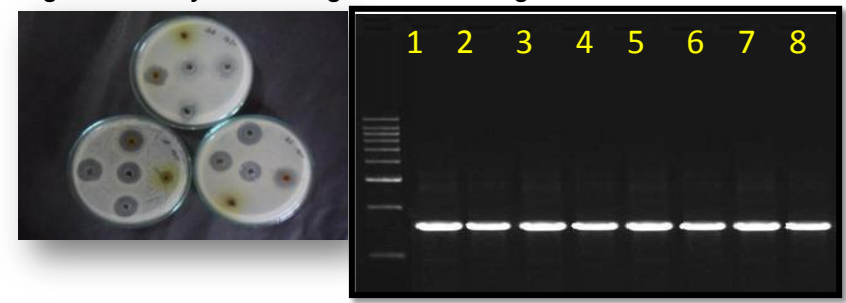

Figure: 3:1: Plant Growth (Rice)

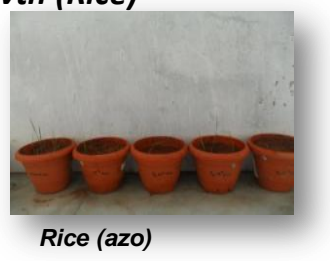

Figure: 5 : Extract of fungus
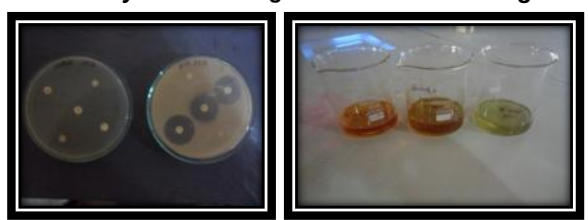

Fig:6:1: G-DNA

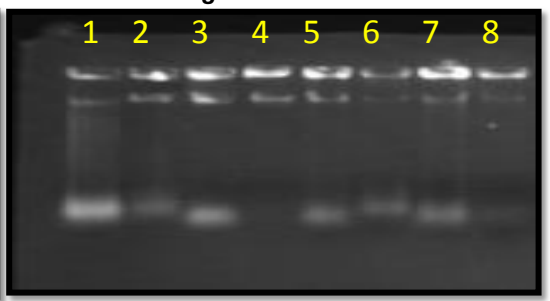

Fig: 6: PCR amplification profile of selected strain Conditions: 1\% agarose gel electrophoresis Lane M: 1 KB DNA Ladder; 1: Sample) 1 KB DNA Ladder (bp):1000, 2000, 3000, 4000, 5000, 6000, 7000, 8000, 9000. Fig :6:1: Genomic DNA of selected two bacterial Isolates.

The bacterial strains especially were proved to be potent biofertilizers for raising green gram and rice. Further experiment was designed to study their probiotic potential in the fishes. The bacterial strains especially ralstonia beneficial effect on the fish culture tank, by enhancing the growth and production of fish. Mass culture was prepared. The mortality in $\%$ is determined after the formula (A-N-B) $\mathrm{Z}^{-1} 100$, with $\mathrm{A}=$ number of dead larva after $24 \mathrm{~h} ; \mathrm{N}=$ number of dead larva before the addition of test compound; $\mathrm{B}=$ number of dead larva in the negative control; $\mathrm{Z}=$ total number of larva. A mortality of Artemia salina at $10 \mu \mathrm{g} / \mathrm{mL}$ is interpreted as high cytotoxic in bacteria and fungal extract diluted in DMSO. The selected strains were bioassayed in seedling growth. The percentage of seed germination was measured, shoot length and root length were measured in rice and green gram. Antibacterial activity was carried out using disc diffusion method by Muller Hinton Agar (MHA) to find sensitive and resistant.
Zone of inhibition was recorded in $\mathrm{mm}$ and the experiment was performed in duplicate. In bacteria after extraction with ethyl acetate the crude extract was tested for the Artemia salina toxicity assay, which is a simple, rapid and inexpensive bench top assay and considered as a useful tool for preliminary assessment of general toxicity. The best culture is selected from bacteria and fungi. The mass culture of Azotobacter and phosphate solubilizing bacteria are used as biofertilizer in green gram, rice and probiotics of fish. The weight and length of probiotic fish is measured from initial stage, $1^{\text {st }}$ week, $2^{\text {nd }}$ week and $3^{\text {rd }}$ week. The fungal strains are isolated from root, stem, leaf. Then the extract of fungus such as Aspergillus niger, Alternaria sp., Aspergillus flavipes, Mucor sp., Aspergillus terreus, Aspergillus flavus were inoculated in the petriplates leaf. In fungi after extraction with ethyl acetate the crude extract was tested for the Artemia salina toxicity assay, which is a simple, rapid and 
inexpensive bench top assay and considered as a useful tool for preliminary assessment of general toxicity.

\section{References}

Alexander, M. 1978. "Introduction to soil Microbiology".2nd Ed.Wiley Eastern Ltd., New Delhi, pp. 467.

Becking, J.H. 1971. "Biological nitrogen fixation and its economic significance". In: Nitrogen-15 in sil plants studies IAEA-Pl-341/14. Vienna, Int. Atomic Energy Agency, pp.189-222.

Chandrasekaran, S. 1966. "Studies on the interrelationship between plants and soil microorganisms in respect to phosphorous solubilization". Ph.D. Thesis, Annamalai University, Parangipettai, India, pp. 190.

Glick, B.R. 1995. "The enhance of plant growth of free-living bacteria". Can. J. Microbial., No. 41, pp.109-117.

Lee, K.D., Bai, Y., Smith, D., Han, H.S., and Supanjani, S. 2005. "Isolation of plant growth promoting endophytic bacteria from bean nodule". Res. J. Agric. Biol. Sci., No. 1(3): pp. 232236.
Perez, E., Sulbaran, M., Bali, M.M. and Yarzabal, L.A. 2007. "Isolation and characterization of mineral phosphatesolubilizing bacteria naturally colonizing a limonitic crust in the southeastern Venezuelan region. Soil Biol. Biochem., No. 39, pp.2905-2914.

Shende, S.T., Apte, R.G., Singh. 1977. "Influence of Azotobacter on germination of rice and cottonseeds". Curr. Sci., No. 46(19): pp.675-676.

Subba Rao. N.S. 1997. Biofertilizers in agriculture and forestry. Oxford and IBH Publishing Co. Pvt. Ltd. New Delhi, pp. 242.

Subba, R.N.S. 1999. Soil Microbiol., Vol 4, USA: Science Publishers Inc.

Vessey, J.K. 2003. "Plant growth promoting rhizobacteria as biofertilizers". Plant Soil, No.255, pp. 571-586.

Zahran, H.H. 1999. "Rhizobium-legume symbiosis and Nitrogen-fixation under severe conditions and in an arid climate". Microbiol. Mol. Biol. Rev., pp. 968-989.

Zaidi, A., Mohammad, S. 2006. "Coinoculation effects of phosphate solubilizing micro-organisms and glomus fasciculatum on green grambrady rhizobium symbiosis", Agri. Sci., No. 30, pp. 223-230.

\section{How to cite this article:}

Soma Prabha, A. 2016. Potential Use of Azotobacter and Phosphate Solubilizing Bacteria as Biofertilizer. Int.J.Curr.Microbiol.App.Sci. 5(10): 79-90. doi: http://dx.doi.org/10.20546/ijcmas.2016.510.010 